\title{
Phytochemical screening, antioxidant and antimicrobial activities of Acalypha ciliata plant
}

\author{
Oluwakayode Odeja, Christiana Ene Ogwuche, Elias Emeka Elemike and Grace Obi
}

\begin{abstract}
Background: Phytochemical screening, antioxidant and antimicrobial activities of hexane, ethylacetate and methanol crude extracts of Acalypha ciliata plant was studied in this work. This plant according to folk medicine has been reported to be used for treatment of female sterility, dressing of sores and schistosomiasis.

Methods: The preliminary screening of the various extracts was carried out using standard methods and the results revealed the presence of flavonoids, tannins, alkaloids, reducing sugar, anthraquinones, resins and glycosides. The antimicrobial screening was carried out using the following organisms; Staphylococcus aureus, Eshericha coli, Bacillus subtilis, Pseudomonas aeruguinosa, Salmonella typhi, Klebsiellae pneumoniae, Candida albicans, Aspergillus niger, Penicillium notatum and Rhizopus stolonifer. The free radical scavenging capacity using hydrogen peroxide was equally determined to evaluate the antioxidant activities of the extracts.

Results: The result obtained showed that Acalypha ciliata extracts have interesting pharmacological active compounds and antimicrobial effects, and as such could be used in ethno medicine for treatment of bacterial infections and ailments.

Conclusion: The extracts of Acalypha ciliata plant contains notable chemical compounds that are responsible for its antioxidant and antimicrobial activity. Further investigations on the chemical compositionsand possible isolation of active ingredients would be carried out.
\end{abstract}

Keywords: Antioxidant, Antimicrobial, Acalypha ciliata, Phytochemicals, Organisms

\section{Background}

Herbal and natural products of traditional medicine have been used by men since the advent of human race. Every culture, including western culture has evolved indigenous system of traditional healing [1]. Traditional healing in different cultures has a long history of ancestors creating primitive medicine during their struggle against natural calamities and diseases. Equally while searching for food; the ancient humans discovered that some foods have specific properties of relieving or eliminating certain diseases and maintaining good health [2].

In recent years, secondary plant metabolites have been extensively investigated as a source of medicinal agents. It is anticipated that phytochemicals with good antibacterial

\footnotetext{
* Correspondence: grace.ann86@yahoo.com

Federal University of Petroleum Resources, Effurun, Delta State, Nigeria
}

activity will be used for the treatment of bacterial, fungal and viral infections [3]. During the last two decades, there has been a considerable increase in the study and use of medicinal plants all over the world, especially in advanced countries. There was also a tremendous increase in the international trade and commercial exploitation of herbal medicines over the counter labeled products. In some countries, herbal medicines are still a central part of the medical system e.g. China, Ethiopia, Argentina and Papua New Guinea [4-7].

Antioxidants have become synonymous with good health; they are a class of compounds thought to prevent certain types of chemical damage caused by an excess of free radicals, charged molecules that are generated by a variety of sources including, smoking, pesticide and fumes from exhaust. Destroying free radicals may help 
fight cancer, heart diseases, stroke and other immune compromising diseases $[8,9]$.

Interest has increased recently in finding naturally occurring antioxidants for use in foods or medicinal materials to replace synthetic antioxidants which are being restricted due to their carcinogenicity [10].

Virtually, all medicinal plants contain large amounts of antioxidants such as polyphenols, which can play an important role in absorbing and neutralizing free radicals; many of these phytochemicals possess significant antioxidant capacities that are associated with lower occurrence and lower mortality rate of several human diseases [11].

Acalypha cilita is specie in the botanical family Euphorbiaceae. It occurs widely in Africa where it is eaten as a vegetable, or fed to animals. In West Africa and East Africa it is used as a medicinal plant [12]. In Nigeria Acalypha ciliata is known locally as Efiri or Owu in Yoruba land and Agukwu in Igbo land. In Cote d'voire, the leaf decotion is drunk to treat female sterility; In Ghana, mashed leaves are applied as a dressing to sores, whereas in East Africa, a root infusion is taken to treat schistosomiasis and in Senegal, Benin and Nigeria, the leaves are eaten as vegetable [13].

The purpose of this research is to evaluate the phytochemicals, antimicrobial and antioxidant activities of this plant since it is been eaten as vegetables.

\section{Method}

\section{Sample preparation}

Acalypha ciliata plant was purchased from Ojee market in Ibadan North-East Local Government and Obada market, Tapa in Ibarapa North Local Government, both in Oyo state, Nigeria. The plant was identified and authenticated at Herbarium unit of Botany department, University of Ibadan, Oyo state, Nigeria. The vegetables was picked to remove debris, cut into small pieces and air dried for 14 days inside the laboratory and later milled into mesh sizes.

\section{Preparation of extracts}

Two hundred eighty grams of dried and milled plant materials were extracted successively with Soxhlet extractor at temperature of $80^{\circ} \mathrm{C}$. Each of the solvent; hexane, ethyl acetate and methanol were allowed to remain in contact with the plant material for $12 \mathrm{~h}$; the extracts were evaporated to dryness using rotary evaporator and $5 \mathrm{~g}, 9.7 \mathrm{~g}$ and $14 \mathrm{~g}$ of the extract respectively were obtained.

\section{Phytochemical analysis}

The extracts were analyzed for the presence of alkaloids, resins, tannins, saponins, flavonoids, glycosides, phenols, anthraquinones, cardiac glycosides, steroids, phlobatannins, reducing sugars [14-17].

\section{Test for alkaloids}

$0.2 \mathrm{~g}$ of extracts was shaken with $1 \% \mathrm{HCl}$ for two minutes. The mixture was filtered and drops of Dragendorff's reagent added. Formation of a precipitate indicated the presence of alkaloids.

\section{Test for Saponins}

$0.2 \mathrm{~g}$ of extracts was shaken with $5 \mathrm{ml}$ of distilled water in a test tube. Frothing which persists on warming was taken as evidence for the presence of saponins.

\section{Test for tannins}

$0.2 \mathrm{~g}$ of extracts was stirred with distilled water and filtered. Ferric chloride was added to the filtrate. A blueblack, green or blue-green precipitate was taken as an evidence for the presence of tannins.

\section{Test for Steroids (Salkowski's test)}

$0.2 \mathrm{~g}$ of the extracts was dissolved in $2 \mathrm{ml}$ of chloroform. Concentrated sulphuric acid was carefully added to form a lower layer. A reddish-brown colour at the interphase indicated the deoxy sugar characteristics of cardenolides.

\section{Test for cardiac-active glycoside (Keller-Killani Test)}

$0.2 \mathrm{~g}$ of the extracts was dissolved in $2 \mathrm{ml}$ of glacial acetic acid containing one drop of ferric chloride solution followed by the addition of $1 \mathrm{ml}$ of concentrated sulphuric acid. A brown ring at the interface confirmed the presence of cardiac glycoside.

\section{Test for reducing sugars}

$0.2 \mathrm{~g}$ of the extract was shaken with distilled water and filtered. The filtrate was boiled with drops of Fehling's solution A and B for two minutes. An orange precipitate on boiling with the Fehling's solution indicated the presence of reducing sugars.

\section{Test for flavonoids}

A little amount of magnesium powder and few drops of concentrated hydrochloric acid were added to $3 \mathrm{ml}$ of the extracts. A red or intense red colouration indicated the presence flavonones.

\section{Test for resins}

Five milliliters of copper acetate solution was added to $5 \mathrm{ml}$ of the methanolic extract. The resulting solution was shaken vigorously and allowed to separate. A green coloured solution is an evidence of the presence of resin.

\section{Test for anthraquinones}

$0.2 \mathrm{~g}$ of the extracts was shaken with $4 \mathrm{ml}$ of benzene. The mixture was filtered and $2 \mathrm{ml}$ of $10 \%$ ammonia solution was added to the filtrate. The mixture was shaken and the presence of pink, red or violet colour in the 
ammonical (Lower) phase indicated the presence of free anthraquinones.

\section{Test for phenols}

$0.2 \mathrm{~g}$ of methanol extract was dissolved in Ferric chloride solution. A green or dirty green precipitate indicated the presence of phenolic compound.

\section{Test for phlobatannins}

The extracts $(0.5 \mathrm{~g})$ was dissolved in distilled water and filtered. The filtrate was boiled with $2 \% \mathrm{HCl}$ solution. Red precipitate shows the presence of Phlobatannins.

\section{Test for glycosides}

The extracts was hydrolyzed with $\mathrm{HCl}$ solution and neutralized with $\mathrm{NaOH}$ solution. A few drops of Fehlings solution A and B were added. Red precipitate indicates the presence of glycosides.

\section{Scavenging of hydrogen peroxide}

The ability of the extracts to scavenge hydrogen peroxide was determined according to the method by Nabavi et al, 2008a and 2009a [18, 19]. A solution of hydrogen peroxide $(2 \mathrm{mM})$ was prepared in phosphate buffer ( $\mathrm{pH} 7.4)$.
The concentration of hydrogen peroxide was determined by absorption at $285 \mathrm{~nm}$ using a UV/Vis spectrophotometer. The samples at ' $1 \mathrm{mg} / \mathrm{ml}, 0.5 \mathrm{mg} / \mathrm{ml}, 0.25 \mathrm{mg} / \mathrm{ml}$, $0.125 \mathrm{mg} / \mathrm{ml}$ and $0.0625 \mathrm{mg} / \mathrm{ml}$ ' were added to $\mathrm{H}_{2} \mathrm{O}_{2}$. The decrease in absorbance of $\mathrm{H}_{2} \mathrm{O}_{2}$ at $285 \mathrm{~nm}$ was measured spectrophotometrically after ten minutes $(10 \mathrm{~min})$ against a blank solution containing the test sample in phosphate buffer saline (PBS) without $\mathrm{H}_{2} \mathrm{O}_{2}$ and blank solution containing phosphate buffer without hydrogen peroxide (control). All the tests were performed in triplicate. The percentage of hydrogen peroxide scavenged by the extracts was calculated as follows:

$$
\left.\% \text { Scavenged }\left[\mathrm{H}_{2} \mathrm{O}_{2}\right]=\left(\mathrm{A}_{\mathrm{c}}-\mathrm{A}_{\mathrm{s}}\right) / \mathrm{A}_{\mathrm{c}}\right] \times 100
$$

Where $A_{c}$ is the absorbance of the control and $A_{s}$ the absorbance in the presence of the sample of extract and standard $[18,19]$. The values of $\%$ inhibition were obtained from Eq. 1. For the 50 \% Inhibitory Concentration $\left(\mathrm{IC}_{50}\right)$ evaluation of the extract, graphs showing the concentration of the test samples (hexane extract, ethyl acetate extract, methanol extract and the alpha tocopherol) versus \% Inhibition $\left(\% \mathrm{H}_{2} \mathrm{O}_{2}\right.$ reduction) were plotted and shown in Figs. 1a, b, c and d.
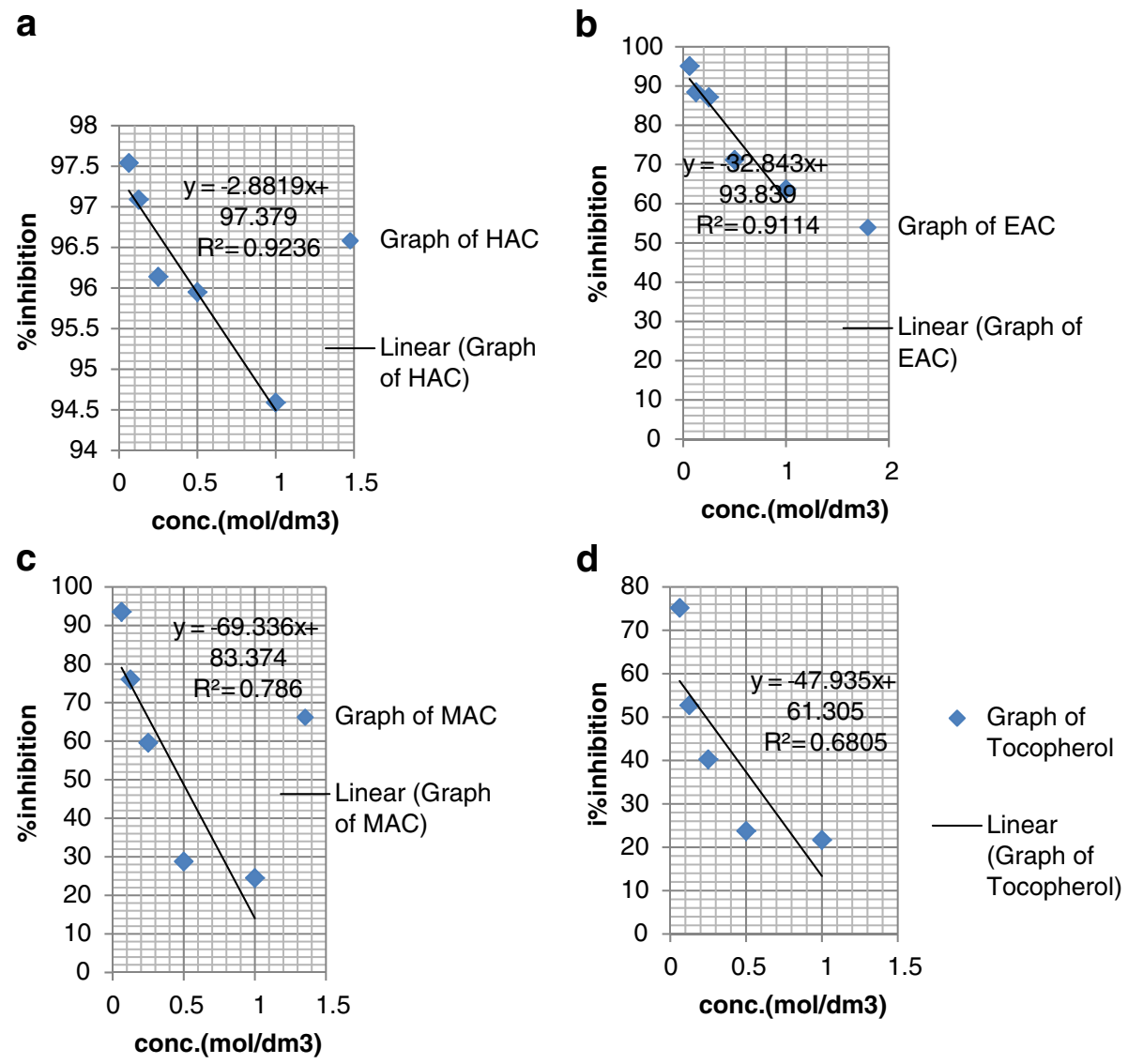

Fig. $1 \mathbf{a}, \mathbf{b}, \mathbf{c}, \mathbf{d}$ Plots of \% inhibition against concentration for HAC, EAC, MAC, a-tocopherol (control) respectively showing the $I C_{50}$ 
Preparation of graded concentration of the samples

One thousand milligram of each sample was weighed and dissolved into $5 \mathrm{ml}$ of the solvent of extraction in order to obtain proper dissolution. From the $200 \mathrm{mg} / \mathrm{ml}$ solution, $2.5 \mathrm{ml}$ was taken into another sample bottle and $2.5 \mathrm{ml}$ of solvent was added to give $100 \mathrm{mg} / \mathrm{ml}$, from this, $2.5 \mathrm{ml}$ is taken into another sample bottle and $2.5 \mathrm{ml}$ of solvent was added to give $50 \mathrm{mg} / \mathrm{ml}$ solution. From the $50 \mathrm{mg} / \mathrm{ml}$ solution, $2.5 \mathrm{ml}$ was taken into another sample bottle and $2.5 \mathrm{ml}$ of solvent added to give $25 \mathrm{mg} / \mathrm{ml}$ solution. Similar procedure was followed to obtain the $12.5 \mathrm{mg} / \mathrm{ml}$ and $6.25 \mathrm{mg} / \mathrm{ml}$ concentrations, using dry filter paper dispersion method.

\section{Organisms}

Bacteria- S.a : Staphylococcus aureus, E.c : Escherichia coli, B.sab: Bacillus subtilis, Ps. a : Pseudomonas aeruguinosa, Sal. $t$ : Salmonella typhi, Klebs : Klebsiella pneumoniae.,

Fungi- C. a : Candida albicans, A. $n:$ Aspergillus niger, Pen : Penicillum notatum, Rhi. : Rhizopus stolonifer.

-ve: Negative control; Methanol for methanolic extract, ethylacetate for ethylacetate extract and hexane for hexane extract.

+ve: Positive control; Gentamicin $10 \mu \mathrm{g} / \mathrm{ml}$ (bacterial) and Tioconazole $70 \%$ (fungi).

\section{Antimicrobial screening}

The microbes used were suspended in suitable nutrition media and was poured into a sterile petri-dish and allowed to incubate for $24 \mathrm{~h}$ at $37{ }^{\circ} \mathrm{C}$. Suitably cut circular filter paper pieces containing 100, 50, 25, 12.5, $6.25 \mathrm{mg} / \mathrm{mL}$ antibiotic solutions test samples and standard were introduced into the media. Then the pieces were placed on the nutritional microbial media all over with suitable gaps in between and incubated again.

After $24 \mathrm{~h}$ of incubation, the plates were removed and the diameter of the zone of inhibition of test and standard samples were measured in millimeters.

By comparing the areas of zone of inhibition of test extracts with standard, the concentration and potency of test samples were determined.

\section{Results}

The preliminary phytochemical screening revealed the presence of alkaloids, saponins, flavonoids, tannins, reducing sugar, phenols, glycosides and resins in some of the extracts (hexane, ethylacetate, methanol) as shown in the Table 1. The methanol extract shows the presence of saponins, tannins, alkaloids, reducing sugars, phenols, glycosides and resins; the ethyl acetate extract shows only alkaloids while the hexane extract shows the presence of alkaloids and flavonoids.

The ability of the extracts to scavenge hydrogen peroxide was determined according to the method by Nabavi et al,; 2008a and 2009a [18, 19]. In the hydrogen peroxide scavenging radical method, the percentage inhibition of the methanolic extract was in the range of $24.53 \%-93.56 \%$. The lowest concentration $(0.0625 \mathrm{mg} / \mathrm{mL})$ showed the highest percentage inhibition value $(93.56 \%)$. There is a characteristic increase in inhibition as the concentration decreases. The ethylacetate extract also showed similar trend as revealed in Table $2(63.68 \%$ at $1.0 \mathrm{mg} / \mathrm{mL}, 71.19 \%, 87.17 \%$, $88.43 \%$ at $0.5 \mathrm{mg} / \mathrm{mL}, 0.25 \mathrm{mg} / \mathrm{mL}, 0.125 \mathrm{mg} / \mathrm{mL}$ respectively, and $95.09 \%$ at $0.0625 \mathrm{mg} / \mathrm{mL}$ ). The hexane extract followed similar trend, showing $94.59 \%$ at $1 \mathrm{mg} / \mathrm{mL}$ and $95.95 \%, 96.14 \%, 97.09 \%$ at $0.5 \mathrm{mg} / \mathrm{mL}, 0.25 \mathrm{mg} / \mathrm{mL}$, $0.125 \mathrm{mg} / \mathrm{mL}$ respectively and $97.94 \%$ at $0.0625 \mathrm{mg} / \mathrm{mL}$. At the lowest concentration of $0.0625 \mathrm{mg} / \mathrm{mL}$ the percentage inhibition was the highest for all the extracts.

\section{Discussion}

The results of the phytochemical screening shows that the methanol extract contains saponins, tannins, alkaloids, reducing sugar, phenols, glycoside and resins, while the hexane extract contains flavonoids and alkaloids and the ethyl acetate extract only contain the alkaloids.

The $\mathrm{IC}_{50}$ (the concentration of the samples required to scavenge $50 \%$ of the peroxide radicals) was actually used to examine the antioxidant effectiveness of the samples. The lower the $\mathrm{IC}_{50}$, the greater the overall effectiveness of the suspected antioxidant sample in question. From the results obtained, it was revealed that the synthetic antioxidant ( $\alpha$-tocopherol) showed the best antioxidant effectiveness with $\mathrm{IC}_{50}$ of 0.24 as shown in Fig. 1d. However, the test samples; $\mathrm{HAC}, E A C$, and $M A C$ had $\mathrm{IC}_{50}$ of $16.44,1.34$ and 0.481 respectively and shown in the Figs. 1a, b and c. Therefore, the synthetic antioxidant ( $\alpha$-tocopherol) was more effective than samples, although they are good antioxidants. The trend thus: $\alpha$ - tocopherol $>M A C>E A C>H A C$ (order of decreasing antioxidant effectiveness). Noumedem et al. 2013, reported the

Table 1 Different constituents of the various extracts of Acalypha ciliata plant

\begin{tabular}{|c|c|c|c|c|c|c|c|c|c|c|c|c|}
\hline Solvent & Saponin & flavonoid & Tanin & Phlobatannin & Steroid & $\begin{array}{l}\text { Cardiac } \\
\text { Glycoside }\end{array}$ & Akaloid & $\begin{array}{l}\text { Reducing } \\
\text { sugar }\end{array}$ & Phenol & Anthraquinone & Glycosides & Resin \\
\hline HAC. & - & + & - & - & - & - & + & - & - & - & - & - \\
\hline EAC & - & - & - & - & - & - & + & - & - & - & - & - \\
\hline MAC & + & - & + & - & - & - & + & + & + & - & + & + \\
\hline
\end{tabular}

HAC hexane extract of Acaylpha ciliata, EAC ethylacetate extract of Acaylpha ciliate, MAC methanol extract of Acaylpha ciliate 
Table 2 The percentage inhibition (antioxidant levels) of the different concentrations of the three different extracts

\begin{tabular}{llllc}
\hline Conc. $\left(\mathrm{mol} / \mathrm{dm}^{3}\right)$ & HAC & EAC & MAC & a-Tocopherol \\
\hline 1.0 & 94.59 & 63.68 & 24.53 & 21.69868 \\
0.5 & 95.95 & 71.19 & 28.79 & 23.7504 \\
0.25 & 96.14 & 87.17 & 59.60 & 40.2791 \\
0.125 & 97.09 & 88.43 & 76.05 & 52.73975 \\
0.0625 & 97.54 & 95.09 & 93.56 & 75.19368 \\
\hline
\end{tabular}

antioxidant activities of the methanol extract, hexane, ethyl acetate and residual fractions of Acalypha manniana with all the extract especially the residual fractions displaying important radical scavenging activities against 2-diphenyl-1-picryl hydrazyl hydrate (DPPH) $\left(\mathrm{RaS}_{50}=3.34-4.80 \mu \mathrm{g} / \mathrm{mL}\right)$ when compared with Lascorbic acid used as reference antioxidant $\left(\mathrm{RaS}_{50}=\right.$ $1.74 \mu \mathrm{g} / \mathrm{mL}$ ) [20]. These observations demonstrate that the Acalypha species are free radical inhibitors or scavengers acting possibly as primary antioxidants. This is very promising in the perspective of new antioxidant discovery from plant extracts.

According to the antimicrobial results, at a high concentration of $100 \mathrm{mg} / \mathrm{mL}$, it was observed that the methanol, ethyl acetate and hexane extracts of all the tested isolates exhibited good antibacterial and antifungal activities. At a low concentration of $12.5 \mathrm{mg} / \mathrm{mL}$, the hexane extracts could no longer inhibit the growth of the micro organisms but the ethyl acetate and methanol extracts was still very active with the methanol extract showing the greatest inhibition.

All the extracts were no longer susceptible to fungal growth at $12.5 \mathrm{mg} / \mathrm{mL}$ except the methanol extract which only inhibited the growth of Candida albicans and Aspergillus niger at this concentration. This means that the minimum bactericidal concentration for the hexane extract is $25 \mathrm{mg} / \mathrm{ml}$ except for Salmonella typhii and Klebsiella pneumoniae which is $50 \mathrm{mg} / \mathrm{mL}$ as shown in Table 3.

This study has shown that the methanol extract of this plant possess high antimicrobial activities even at low concentration of $6.25 \mathrm{mg} / \mathrm{mL}$; compared to the ethyl acetate and hexane extract placing it on a broad spectrum plane.

In a similar study using Acalypha manniana, the methanol extract prevented the growth of all tested microorganisms with minimum inhibitory concentration (MIC) values ranging between 0.12 and $2.04 \mathrm{mg} / \mathrm{mL}$ for bacteria with Staphylococcus aureus being the most resistant [20]. In the case of Acalypha indica as reported by Govindarajan et al., 2008; the specie inhibited the growth of gram + ve bacteria but did not for gram -ve except Pseudomonas aerugonisa [21]. This may be due to the composition of gram -ve bacteria which is mainly lipopolysaccharide layer along with proteins and phospholipids. Acalypha
Table 3 The zones of inhibition of the isolates at different concentrations compared to the control drugs

\begin{tabular}{lllllllllll}
\hline MAC & & & & & & & & & & \\
Conc. $(\mathrm{mg} / \mathrm{mL})$ & Sa & Ec & B.Sab & Ps.a & Sal & Klebs & C.a & A.n & Rhi & Pen \\
100 & 22 & 20 & 22 & 20 & 24 & 26 & 18 & 18 & 16 & 14 \\
50 & 18 & 18 & 18 & 18 & 20 & 22 & 16 & 14 & 12 & 12 \\
25 & 14 & 16 & 16 & 16 & 18 & 20 & 14 & 12 & 10 & 10 \\
12.5 & 12 & 12 & 14 & 12 & 14 & 16 & 12 & 10 & - & - \\
6.25 & 10 & 10 & 10 & 10 & 10 & 12 & 10 & - & - & - \\
HAC & & & & & & & & & & \\
100 & 16 & 18 & 16 & 16 & 14 & 12 & 16 & 12 & 14 & 14 \\
50 & 14 & 16 & 14 & 14 & 10 & 10 & 12 & 10 & 10 & 10 \\
25 & 12 & 12 & 12 & 10 & - & - & 10 & - & - & - \\
12.5 & - & - & - & - & - & - & - & - & - & - \\
6.25 & - & - & - & - & - & - & - & - & - & - \\
EAC & & & & & & & & & & \\
100 & 16 & 16 & 20 & 20 & 16 & 16 & 16 & 14 & 16 & 16 \\
50 & 14 & 14 & 18 & 18 & 14 & 14 & 14 & 12 & 14 & 14 \\
25 & 10 & 12 & 16 & 16 & 12 & 10 & 10 & 10 & 10 & 10 \\
12.5 & - & 10 & 14 & 12 & 10 & - & - & - & - & - \\
6.25 & - & - & 10 & 10 & - & - & - & - & - & - \\
$-v e$ & - & - & - & - & - & - & - & - & - & - \\
$+v e$ & 38 & 38 & 40 & 38 & 38 & 38 & 28 & 28 & 26 & 28 \\
\hline
\end{tabular}

wilkesiana aqeous extract did not exert any inhibitory effect on Klebsiella pneumoniae and Proteus mirabilis but the ethanol extract was active with the MIC ranging from 0.25 and $32 \mathrm{mg} / \mathrm{mL}$ [22]. From the comparative studies and the results of our research, Acalypha manniana specie seems to be the most bioactive since it inhibits the growth of gram -ve and gram + ve bacteria as well as fungi.

\section{Conclusion}

The results of this study indicated that the plant contains some major bioactive compounds that inhibit the growth of micro-organisms, thereby showing great potency as effective source of drugs. The phytochemical analysis also reveals that the plant contains similar constituents which are useful for medicinal purpose. The high antioxidant activities of the plant indicates that, it will be potent in fighting diseases associated with oxidative compounds. This work reassures the safety in the consumption of this plant as the general trend in its edibility is diminishing.

\footnotetext{
Competing interests

Oluwakayode Odeja, Christiana Ene Ogwuche, Elias Emeka Elemike and Grace Obi declare that they have no competing interests.
}

Authors' contributions

OO carried out the samples collection and took part in the laboratory analysis and write up. OCE was involved in the antioxidant and antimicrobial 
analysis as well as results interpretation. EEE was involved in the laboratory work as well as technicalities and made necessary corrections in the write up. OG performed part of the laboratory work, was involved in the plant extraction process, result interpretation and made necessary correction in the write up. All authors read and approved the final manuscript.

\section{Acknowledgment}

The authors are grateful to the technologists of Department of Chemistry of the Federal University of Petroleum Resources Effurun for their assistance during the course of this research.

Received: 27 October 2015 Accepted: 2 June 2016

Published online: 21 June 2016

\section{References}

1. Atkinson DC, Boura AL, Hicks R. Observation on the pharmacological properties of inflammatory exudate. EurPharmacol. 1968;8:348-53.

2. Baliga MS, Jagetia GC, Ullor JN, Baliga MP, Venlcatesh P, Reddy R, Rao KV, Baliga BS, DeviS, Raju Sk, Veeresh V, Reddy TK, Bairy KL. The evaluation of the acute toxicity and long term safety of hydroalcoholic extract of sapthaparma (Alstoniascholaris) in mice and rats. Toxicol Lett. 2004;151:317-26.

3. Okigbo RN, Omodamiro OD. Antimicrobial effects of leaf extracts of pigeon pea (cajanus cajan L mill sp) on some human pathogens. J Herbs Spices Med Plant. 2006;12:117-27.

4. Liu CX. Development of Chinese medicine based on pharmacology and therapeutics. J Ethnopharmacol. 1987;19:119-23.

5. Desta B. Ethiopia traditional herbal drugs part II antimicrobial activity of 63 medicinal plants. J Ethnopharmacol. 1993;42:129-39.

6. Anesini C, Perez C. Screening of plants used in Argentine folk medicine for antimicrobial activity. J Ethnopharmacol. 1993;39:119-28.

7. Nick A, Rali T, Stitcher O. Biological screening of traditional medicinal plants from Papua New Guinea. J Ethnopharmacol. 1995:49:147-54.

8. Yi-Fang CS, Jie WU, Xian H, Li RH. Antioxidant and Antiproferative activities of commom vegetables. Rev J Agric Food Chem. 2002;50:6910-6.

9. Arouma Ol. Methodological considerations for characterizing potential antioxidant actions of bioactive components in food plants. Mut Res. 2003;523:9-20.

10. Velioglu YS, Mazza G, Gao L, Oomah BD. Antioxidant activity and total phenolics in selected fruits vegetables and grain products. J Agric Food Chem. 1998:46:4113-7.

11. Anderson KJ, Tender SS, Gobeille A, Cremin P, Waterhouse AL, Stteinbery FM. Walnut polyphenolics inhibits in vitro human plasma and LDL oxidation. Biochemical and molecular action of nutrients. J Nutr. 2001;131: $2837-42$.

12. Schmelzer GH, Gurib-Fakim A (eds). Plant Resources of tropical Africa. Medicinal plants 1. PROTA Foundation, Wageningen, Netherlands/Backhuys publishers. Leiden, Netherlands ICTA, Wageningen, Netherlands. 2008; 2(1):791.

13. Burkill HM. The useful plants of the west tropical Africa. 2nd ed., families E-I, Royal Botanical Gardens, Kew, Richmond, United Kingdom. 1994; 2: 636.

14. Sofowara A. Medicinal plants and Traditional medicine in Africa, Spectrum Book LTD, Ibadan, Nigeria.1993; 289.

15. Herborne JB. Phytochemical methods $3^{\text {rd }}$ Edn. London: Chapman and Hall Ltd.; 1973. p. 135-203.

16. Okwu DE. Evaluation of the chemical composition of indigenous species and flavoring agents. Global J Pure Appl Sci. 2001;7(3):455-9.

17. Rahilla TN, Rukh S, Ziaidi AA. Phytochemical screening of medicinal plants belonging to Euphorbiaceae. Pak Vet J. 1994:14:160-2.

18. Nabavi SM, Ebrahimzadeh MA Abavi SF, Hamidinia A, Bekhradnia AR. Determination of antioxidant activity, phenol and flavonoids content on parrotiapersicamey.Pharmacology online, 2008a;2: 560-567.

19. Nabavi SM, Ebrahimzadeh MA, Nabavi SF, Jafari M. Free radical scavenging activity and antioxidant capacity of Eryngium cancasicumTrantv and Froripia subpinnata. Pharmacol Online. 2008;3:19-25.
20. Noumedem JAK, Tamokou JD,Teke GN, Momo CD, Kuete V, Kuiate JR. Phytochemical analysis, antimicrobial and radical scavenging properties of Acalypha manniana leaves, springerplus 2013, 2:503

21. Govindarajan M, Jabanesan A, Reetha D, Amsath R, Pushpanathan T, Samidurai K. Antibacterial activity of Acalypha Indica L. Eur Rev Med Pharmacol Sci. 2008;12:299-302.

22. Alade PI, Irobi ON. Antimicrobial activities of some crude leaf extract of Acalypha wilkesiana. J Ethnopharmacol. 1993;39:171-4.

\section{Submit your manuscript to a SpringerOpen ${ }^{\circ}$ journal and benefit from:}

- Convenient online submission

- Rigorous peer review

- Immediate publication on acceptance

- Open access: articles freely available online

- High visibility within the field

- Retaining the copyright to your article 